\title{
PENGEMBANGAN BAHAN AJAR FISIKA EKSPERIMEN BERBASIS PROYEK UNTUK MENINGKATKAN PENGUASAAN SCIENTIFIC METHOD CALON GURU
}

\author{
Sutrio $^{1^{*}}$, Ahmad Harjono ${ }^{1}$, Hairunisyah Sahidu ${ }^{1}$ \\ ${ }^{1}$ Program Studi Pendidikan Fisika, Universitas Mataram, Indonesia \\ Corresponding author: sutrio_trio@unram.ac.id
}

\section{Article history}

Received : April 20 ${ }^{\text {th }}, 2021$

Revised : April 28 ${ }^{\text {th }}, 2021$

Accepted : May 05 ${ }^{\text {th }}, 2021$

Published : May 20 ${ }^{\text {th }}, 2021$

\begin{abstract}
Abstrak: Mahasiswa calon guru fisika memiliki peranan penting yang sangat strategis dalam memperbaiki proses pembelajaran fisika di sekolah pada masa yang akan datang. Salah satu kelemahan proses pembelajaran di sekolah masih kurangnya penanaman nilai dan semangat Scientific Method. Penelitian ini bertujuan untuk mengembangkan bahan ajar mata kuliah Fisika Eksperimen berbasis proyek yang dapat meningkatkan penguasaan Scientific Method mahsiswa. Bahan ajar ini dikembangkan untuk membantu mahasiswa calon guru dalam proses pembelajaran sehingga dapat meningkatkan penguasaan scientific method. Metode penelitian yang digunakan dalam mengembangkan bahan ajar ini adalah metode Research and Development (R\&D). Untuk mengetahui kelayakan bahan ajar yang dikembangkan dilakukan validasi bahan ajar oleh ahli, respon mahasiswa terhadap bahan ajar dan analisis penguasaan scientific method mahasiswa. Hasil penelitian menunjukkan bahan ajar yang telah dikembangkan layak digunakan dalam pembelajaran, memenuhi uji validasi oleh ahli untuk komponen kelayakan isi, penyajian dan kebahasaan dengan kategori baik. Respon mahasiswa terhadap bahan ajar sangat baik, mudah dipahami dan layak untuk digunakan. Bahan ajar yang diuji cobakan dalam pembelajaran Fisika Eksperimen mampu meningkatkan penguasaan scientific method mahasiswa.
\end{abstract}

Kata kunci: bahan ajar berbasis proyek, fisika eksperimen, penguasaan scientific method.

\section{PENDAHULUAN}

Mahasiswa Program Studi Sarjana Pendidikan Fisika FKIP Universitas Mataram merupakan mahasiswa yang sedang disiapkan untuk menjadi calon guru fisika di Sekolah Menengah. Hal ini berarti bahwa, pelaksanaan pembelajaran fisika di sekolah pada masa yang akan datang akan banyak ditentukan oleh mereka. Jika dilihat dari data peserta ujian nasional, jumlah peserta didik yang memilih mata pelajaran fisika sebagai mata pelajaran pilihan jumlahnya paling sedikit dibandingkan mata pelajaran pilihan lainnya, diindikasikan pelaksanaan pembelajaran fisika di sekolah kurang bermakna. Pembelajaran fisika yang kurang bermakna cenderung tidak diminati oleh peserta didik, maka mahasiswa calon guru fisika yang saat ini masih berada dibangku kuliah, diharapkan mampu memperbaiki keadaan tersebut.

Banyak variabel yang menentukan tingkat kebermaknaan suatu pembelajaran di sekolah. Salah satunya kualitas guru. Kualitas guru yang tidak sesuai standar dapat menyebabkan pembelajaran menjadi kurang bermakna. Standar kualitas guru akan menentukan sejauh mana guru dipercaya dan diterima oleh peserta didik. Oleh karena itu masalah kualitas guru tidak bisa dipisahkan dari proses penyiapan guru di LPTK. Artinya, sebagai lembaga yang diberi kepercayaan pemerintah untuk menyiapkan guru fisika, program studi sarjana Pendidikan Fisika FKIP Universitas Mataram juga memilki tanggung jawab atas persoalan pelaksanaan pembelajaran fisika yang kurang bermakna.

Menyadari persoalan tersebut, maka harus ada langkah-langkah strategis dan sistematis yang 
dilakukan oleh program studi pendidikan Fisika FKIP Universitas Mataram. Mahasiswa calon guru fisika harus disiapkan memiliki kemampuan untuk melaksanakan proses pembelajaran yang bermakna. Proses pembelajaran yang digunakan agar menjadi lebih bermakna, sebagaimana diusulkan oleh Lawson (1995: 4), dimulai dari pemberian pertanyaan menantang tentang suatu fenomena, kemudian menugaskan peserta didik untuk melakukan aktivitas, memusatkan pada pengumpulan dan penggunaan bukti, bukan sekedar penyampaian informasi secara langsung dan penekanan hafalan. Menjadikan mahasiswa calon guru mampu menjalankan proses pembelajaran secara bermakna di sekolah, dapat dilakukan dengan cara membiasakan mahasiswa untuk mengikuti perkuliahan bermakna di kampus. Dengan demikian dosen pengajar juga harus menjalankan proses pembelajaran dengan cara yang bermakna.

Fisika Eksperimen merupakan salah satu mata kuliah wajib yang diberikan bagi mahasiswa semester VI di Program Studi Pendidikan Fisika FKIP Universitas Mataram. Capaian pembelajaran matakuliah ini dalam aspek ketrampilan khusus, agar mahasiswa mampu melaksanakan pembelajaran fisika sekolah menengah dengan pendekatan saintifik sesuai dengan karakteristik materi dan karakteristik peserta didik dan mampu mengembangkan kemampuan berfikir dan sikap ilmiah. Mata kuliah ini diharapkan dapat memberikan ketrampilan kepada mahasiswa calon guru fisika untuk merancang dan membuat alat yang digunakan untuk eksperimen yang dapat dipergunakan di sekolah menengah. Agar pembelajaran yang dilaksanakan menjadi bermakna, maka dalam perkuliahan, mahasiswa diwajibkan untuk membuat alat eksperimen fisika dengan melalui tahapan merencanakan desain alat, membuat alat, menguji coba alat dan mengkomunikasikan hasil alat yang telah dibuat.

Dalam pelaksanaan pembelajaran matakuliah ini berdasarkan pengalaman dosen pengajar, banyak mahasiswa mengalami kesulitan di dalam mengerjakan tugas perkuliahan. Hal ini dikarenakan belum adanya bahan ajar tertulis dan hanya menerima penjelasan-penjelasan bagaimana mengerjakan tugas perkuliahan. Oleh karena itu perlunya penyediaan buku ajar yang sangat membantu mahasiswa dalam belajar dan membantu dosen untuk mengajar lebih efektif dan efisien sehingga waktu yang tersedia dapat digunakan untuk membimbing mahasiswa lebih intensif dan melakukan latihan-latihan yang diperlukan untuk pengembangan, yang pada akhirnya akan bermuara pada percepatan penguasaan capaian pembelajaran mata kuliah dari mata kuliah bersangkutan.

Pengembangan bahan ajar Fisika Eksperimen didasarkan pada tahapan-tahapan pembelajaran bermakna sehingga dapat membiasakan mahasiswa menanamkan nilai dan semangat scientific method. Scientific method adalah proses berpikir untuk memecahkan masalah secara sistematis, empiris dan terkontrol. Penguasaan scientific method yang dimiliki mahasiswa dapat dikembangkan pada saat merumuskan masalah, merumuskan hipotesis, mengumpulkan data, menguji hipotesis, dan merumuskan kesimpulan. Dalam pembelajaran berbasis proyek memilki tahap-tahap pembelajaran yang selaras dengan proses Sientific Method (Nurohman, 2007)

Pembelajaran berbasis proyek merupakan pembelajaran yang berpusat pada proses, relatif berjangka waktu, berfokus pada masalah, unit pembelajaran bermakna dengan memadukan konsep-konsep dari sejumlah komponen baik itu pengetahuan, disiplin ilmu atau lapangan. (Sastrika et al., 2013). Pada pembelajaran berbasis proyek kegiatan pembelajarannya berlangsung kolaboratif dalam kelompok heterogen. Pembelajaran berbasis proyek memiliki potensi yang sangat besar untuk melatih proses berpikir mahasiswa untuk memecahkan masalah secara sistematis, empiris dan terkontrol. Oleh karena itu dikembangkan bahan ajar Fisika Eksperimen berbasis proyek yang mampu meningkatkan penguasaan scientific method.

\section{METODE}

Penelitian ini merupakan penelitian pengembangan pendidikan (Educational Research and Development) yang disingkat dengan $\mathrm{R} \& \mathrm{D}$. Jenis penelitian $R$ \& $D$ adalah suatu proses yang digunakan untuk mengembangkan dan memvalidasi produk-produk pendidikan (Sugiyono, 2011). Produk yang dimaksud dalam penelitian ini adalah bahan ajar Fisika Eksperimen berbasis proyek yang akan diterapkan pada perkuliahan Fisika Eksperimen II. Penelitian ini dilaksanakan di Program Studi Pendidikan Fisika FKIP Unram semester Genap Tahun Akademik 2018/2019. Subyek penelitian adalah mahasiswa yang menempuh mata kuliah Fisika Eksperimen II kelas A dan B yang ber jumlah 42 orang.

Pengembangan bahan ajar dalam penelitian ini berpedoman pada Panduan Penulisan Buku Ajar yang disusun oleh Tim Pengembangan Buku Ajar 
FKIP Universitas Mataram tahun 2015 dengan kriteria: 1) isi buku ajar harus memberi peluang kepada peserta didik untuk mengembangkan beberapa ketrampilan, 2) buku ajar memiliki capaian pembelajaran yang jelas, 3) kejelasan dan kebenaran konsep, 4) sesuai dengan kurikulum yang berlaku, 5) menarik minat peserta didik, 6) menumbuhkan motivasi dan menstimulasi aktivitas serta kemampuan berfikir mahasiswa, 7) ilustrasi dan contoh, 8) penggunaan bahasa yang komunikatif, logis dan sitemis, 9) kontekstual dan mutakhir, 10) menghargai perbedaan individu, 11) memantapkan nilai-nilai.

Penelitian dan pengembangan bahan ajar Fisika Eksperimen berbasis proyek ini meliputi 6 tahap yang diadaptasi dari 10 tahap dari penelitian pengembangan Borg dan Gall. (Sugiyono, 2011). Adapun 6 tahapan yang diadopsi dapat dilihat pada Gambar 1.

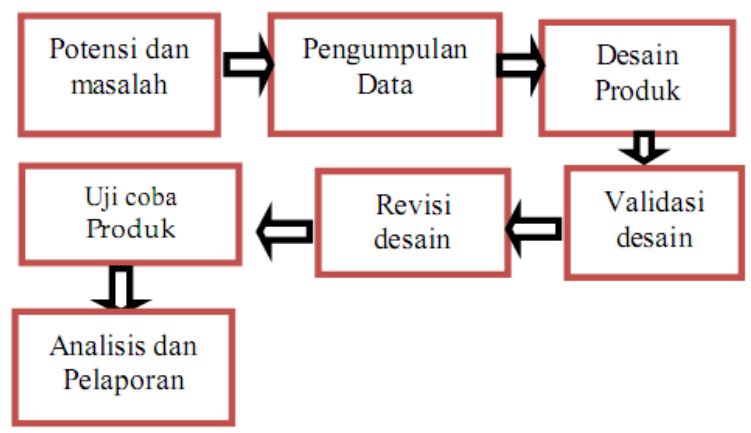

Gambar 1. Tahap Penelitian Metode Research dan Development (R\&D)

Pada awal kegiatan dilakukan analisis potensi dan masalah dalam pembelajaran Fisika Eksperimen dan dilanjutkan pengumpulan data dengan melakukan studi literatur tentang pembelajaran berbasis proyek dan scientific method. Dari data-data yang diperoleh dianalisis dan dijadikan acuan untuk membuat desain bahan ajar. Produk yang dihasilkan pada penelitian ini adalah bahan ajar yang akan digunakan dalam pembelajaran yang akan digunakan untuk meningkatkan kemampuan berpikir kritis. Sebelum digunakan bahan ajar perlu diketahui kelayakan dengan melakukan penilaian kelayakan bahan ajar oleh ahli dengan cara memberikan tanggapan dengan kriteria sangat baik, baik, kurang baik, dan tidak baik. Uji coba produk bahan ajar diterapkan pada perkuliahan Fisika Eksperimen II dan dilakukan observasi keterlaksanaan pembelajaran. dan di akhir perkuliahan mahasiswa diberikan angket untuk mengetahui tanggapan mahasiswa terhadap pembelajaran yang dilaksanakan.

Instrumen yang digunakan untuk mengumpulkan data dalam penelitian ini yaitu:1) Angket skala Likert, terdiri dari angket uji validasi ahli dan angket respon mahasiswa terhadap pembelajaran yang dilaksanakan. Angket uji validasi dimaksudkan untuk memvalidasi desain bahan bahan ajar yang digunakan oleh ahli untuk mengetahui kualitas bahan ajar terutama menyangkut komponen kelayakan isi, komponen penyajian dan komponen kebahasaan. Angket respon mahasiswa dimaksudkan untuk mengetahui respon mahasiswa terhadap pembelajaran fisika eksperimen berbasis proyek yang dilaksanakan; 2) Lembar observasi, untuk mengobservasi aktivitas mahasiswa selama proses pembelajaran untuk mengetahui keterlaksanaan penggunaan bahan ajar, 3)Instrumen penguasaan scientific method untuk mengetahui pengaruh penggunaan bahan ajar fisika eksperimen berbasis proyek dalam meningkatkan penguasaan scientific method mahasiswa calon guru.

Data yang diperoleh dalam penelitian ini berupa data kualitatif dan kuantitatif. Ada empat data yang dikumpulkan yaitu data hasil validasi ahli, data respon mahasiswa terhadap pembelajaran yang dilaksanakan, data hasil observasi keterlaksanaan pembelajaran dan data ketrampilan berpikir kritis. Data yang bersifat kualitatif dianalisis secara deskriptif untuk menemukan kecenderungankecenderungan yang muncul pada saat penelitian sedangkan data kuantitatif dianalis dengan uji statistik.

Indikator keberhasilan penelitian ini adalah: 1) Kriteria keberhasilan dari bahan ajar yang telah dikembangkan, jika bahan ajar yang telah dikembangkan dalam kategori layak/baik digunakan tanpa revisi atau dengan sedikit revisi; 2) Mendapat respon positif dari mahasiswa: 3) Mahasiswa dapat menggunakan bahan ajar yang telah dikembangkan sehingga penguasaan scientitic method meningkat.

\section{HASIL DAN PEMBAHASAN}

\section{Studi Pendahuluan}

Pada tahap studi pendahuluan telah dilakukan analis potensi dan masalah pembelajaran Fisika Eksperimen melalui kegiatan observasi dan wawancara dengan dosen dan mahasiswa yang pernah menempuh matakuliah yang kemudian dikumpulkan datanya digunakan untuk pengembangan desain bahan ajar. Hasil observasi pembelajaran Fisika Eksperimen menunjukkan 
bahwa metode yang digunakan menggunakan metode eksperimen. Mahasiswa melakukan eksperimen dengan menggunakan petunjuk praktikum dan setelah selesai melaksanakan praktikum diminta untuk membuat laporan dan diberikan penilaian. Di dalam petunjuk praktikum mahasiswa diminta membuat alat eksperimen terlebih dahulu setelah alat selesai dibuat digunakan untuk eksperimen dengan mengikuti petunjuk yang ada di dalam petunjuk praktikum. Dalam pembelajaran ini mahasiswa belum dituntut untuk berkreasi memilih sendiri alat eksperimen yang dibuat dan mendesain eksperimen apa yang akan dilakukan. Hal ini nampak bahwa pembelajaran Fisika Eksperimen belum memaksimalkan mengembangkan penguasaan scientific method mahasiswa. Pada saat membuat alat eksperimen mahasiswa masih merasa kesulitan membuat sehingga hasil karya yang dibuat belum sempurna sehingga hasil praktikumnya belum memuaskan karena harus segera menyelesaikan tepat waktu. Kelebihan/potensi pembelajaran Fisika Eksperimen ini adalah mahasiswa membuat alat/set alat sendiri tidak seperti pada pembelajaran mata kuliah lain yang ada praktikumnya seperti pada mata kuliah Fisika Dasar.

Hasil wawancara dengan guru mata pelajaran Fisika dan kajian kurikulum tahun 2013 bahwa pembelajaran Fisika di SMA perlunya menerapkan pembelajaran berbasis proyek. Guru merasakan kesulitan melaksanakan pembelajaran tersebut dikarenakan sewaktu kuliah belum pernah melaksanakan pembelajaran proyek dan terbatasnya peralatan-peralatan yang ada dalam laboratorium.

Studi literatur tentang scientific method dan pembelajaran berbasis proyek dilakukan untuk melihat potensi apabila menerapkan pembelajaran proyek dalam perkuliahan Fisika Eksperimen yang dapat meningkatkan penguasaan scientific method. Dengan demikian akan memberikan pengalaman dan bekal pada mahasiswa sebagi calon guru agar dapat melaksanakan pembelajaran Fisika berbasis proyek sesuai tuntutan kurikulum tahun 2013.

Scientific Method merupakan serangkaian proses ilmiah yang diawali dengan suatu pertanyaan, diikuti pengajuan hipotesis sebagai jawaban sementara atas pertanyaan yang muncul, lalu dilakukan proses pengujian hipotesis melalui eksperimen, dan pada akhirnya disusun kesimpulan sebagai jawaban yang lebih sahih atas pertanyaan pada bagian awal. Bagi para saintis, scientific method dapat digunakan sebagai alat bantu agar mereka tetap fokus pada pertanyaan proyek, mengkonstruksi hipotesis, mendesain dan mengevaluasi eksperimen. Nurahman (2007) berpendapat scientific method adalah jalan untuk membuat dan menjawab pertanyaan ilmiah (scientific questions) melalui observasi dan atau eksperimen. Adapun tahap-tahap scientific method dapat disebutkan terdiri dari: (1) membuat pertanyaan ilmiah, (2) melakukan kajian teoritis, (3) mengkontruksi hipotesis, (4) menjalankan observasi dan eksperimen, (5) menganalisis data dan membuat kesimpulan, (6) melaporkan hasil (publikasi).

Pembelajaran berbasis proyek adalah pendekatan yang telah banyak dipakai oleh dosen di dunia barat. Pembelajaran berbasis proyek adalah metode pembelajaran dimana mahasiswa menerima pengetahuan dan ketrampilan baru melalui suatu tahapan pembelajaran yang sistematis untuk pada akhirnya dapat menghasilkan suatu rancangan, model, prototipe atau produk. Adapun sintak : (1) Starts With the Essential Question (Pembelajaran diawali dengan suatu pertanyaan esensial), (2) Design a Plan for the Project (merencanakan sebuah proyek untuk menjawab pertanyaan), (3) Creates a Schedule (menjadwalkan pelaksanaan, melaksanakan proyek), (4) Monitor the Students and the Progress of the Project (monitoring kemajuan proyek), (5) Assess the Outcome (menguji coba hasil/produk), (6) Evaluate the Experiences (mengevaluasi/releksi terhadap hasil proyek yang sudah dijalankan)

Dari pembahasan di atas bagaimana pendekatan Project Based Learning dapat menfasilitasi proses penanaman nilai dan semangat Scientific Method kepada para mahasiswa. Secara lebih tegas, pola hubungan antara Project Based Learning dengan internalisasi Scientific Method ditunjukan oleh Tabel 1. (Nurahman, 2007) 
Tabel 1. Pola hubungan Pembelajaran Proyek dan Scientific Method

\begin{tabular}{cll}
\hline No & \multicolumn{1}{c}{ Sintak Pembelajaran Proyek } & \multicolumn{1}{c}{ Tahapan Scientific Method } \\
\hline 1. & $\begin{array}{l}\text { Starts With the Essential Question } \\
\text { Design a Plan for the Project }\end{array}$ & $\begin{array}{l}\text { Membuat pertanyaan ilmiah } \\
\text { Melakukan kajian teoritis (research), dan } \\
\text { mengkontruksi hipotesis }\end{array}$ \\
3. & $\begin{array}{l}\text { Creates a Scedulle, Monitor the Students } \\
\text { and Progress of project }\end{array}$ & $\begin{array}{l}\text { Menjalankan observasi dan atau } \\
\text { eksperimen }\end{array}$ \\
4. $\quad \begin{array}{l}\text { Access the Outcome } \\
\text { Menganalisis data dan membuat } \\
\text { k. }\end{array}$ & Evaluate the Expereiences & Melaporkan hasil (publikasi)
\end{tabular}

Berdasarkan Tabel 1, maka dapat dilihat bahwa pendekatan pembelajaran proyek secara teoritis dapat menfasilitasi proses Scientific Method. Dengan demikian, pendekatan pembelajaran proyek dapat digunakan oleh para pengajar (dosen) dalam menanamkan nilai dan semangat Scientific Method kepada para peserta didik (mahasiswa). Hal ini sejalan dengan pembelajaran di era industri 4.0 seperti yang diharapkan oleh kemenristek dikti, mahasiswa memperoleh pengalaman belajar atau aktivitas melalui interaksi dengan kondisi eksternal di lingkungan pembelajarannya (Tyler, 2013). Aktivitas belajar yang mentranformasi materi pembelajaran menjadi pengetahuan bermakna yang dapat digunaka untuk melakukan hal-hal baru (Ornstein \& Hunkins, 2016) dan memberikan kemaslahatan. Fitriningrum et al., (2016) menyatakan penerpan model project based learning berbasis eksperimen efektif untuk meningkatkan penguasaan konsep fisika dan kinerja siswa. Erlinawati et al., (2019) menyatakan pembelajaran project based learning berbasis STEM pada pembelajran fisika baik digunakan karena dapat membuat siswa menjadi lebih aktif dalam kegiatan pembelajaran. Selain itu siswa juga dapat mengeksplor pengetahuan yang dimilikinya serta mengkaitkannya dengan sains, teknologi, enginering, dan matematik sehingga dapat bersaing di era perkembangan abad 21.

Hasil studi literatur di atas digunakan untuk mengembangkan desain baham ajar Fisika Eksperimen berbasis proyek untuk meningkatkan penguasaan scientific method mahasiswa calon guru. Telah dilakukan analisis komponen komponen pembelajaran berbasis proyek dan analisis indikator penguasaan scientific method yang dapat dikembangkan dalam pembelajaran Fisika Eksperimen berbasis proyek.

\section{Desain Bahan Ajar}

Berdasarkan analisis potensi dan masalah dalam studi pendahuluan, dibuatlah desain bahan ajar Fisika Eksperimen berbasis proyek yang dapat meningkatkan penguasaan scientific method. Desain bahan ajar Fisika Eksperimen berbasis proyek dikembangkan dari tahapan pembelajaran proyek yaitu: 1) Membuat pertanyaan dan menentukan Judul Proyek, 2) Membuat Desain/Perencanaan proyek, 3) melaksanakan proyek dan monitoring perkembangan proyek , 4) Menguji coba hasil/produk, 5) Mengkomunikasikan hasil.

Adapun produk bahan ajar yang dikembangkan berisi materi; (BAB I) Fisika Eksperimen Berbasis proyek (BAB II) Penyusunan Proposal (Penentuan Judul, Rancangan Desain, Pembuatan Jadwal kegiatan dan monitoring), (BAB III) Uji Coba Hasil (Merancang Eksperimen Fisika, Analisis Hasil Eksperimen, penarikan kesimpulan), (BAB IV) Komunikasi Hasil (Pembuatan Laporan Akhir, Pembuatan Poster), (BAB V Contoh Pembuatan Alat Eksperimen Fisika).

\section{Hasil Validasi Bahan Ajar}

Bahan ajar yang telah dikembangkan divalidasi untuk penilaian kelayakan dan masukan pakar untuk perbaikan desain bahan ajar. Butir-butir penilaian bahan ajar terdiri dari komponen kelayakan isi, komponen penyajian, komponen kebahasaan. Hasil uji validasi bahan ajar untuk setiap komponen menunjukkan nilai komponen kelayaan isi 83,3\% dengan kriteria layak/baik untuk digunakan, nilai komponen penyajian 82,0 \% dengan kriteria layak/baik untuk digunakan sedangkan nilai komponen kebahasaan 78,2\% dengan kriteria layak/baik digunakan dengan revisi. 
Sutrio et al. (2021). Jurnal Ilmiah Profesi Pendidikan, 6 (1): 126 - 133

DOI: https://doi.org/10.29303/jipp.v6i1.168

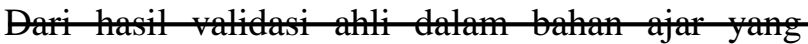
dikembangkan masih terdapat kekurangan dari komponen kebahasaan yang perlu disempurnakan sebelum digunakan untuk keperluan uji coba terbatas.

\section{Pembahasan}

Bahan ajar yang sudah divalidasi dan diperbaiki kebahasaannya diujicobakan pada mahasiswa yang berjumlah 42 orang mahasiswa yang mengikuti perkuliahan Fisika Eksperimen. Setelah selesai pembelajaran mahasiswa diminta untuk memberikan respon melalui angket untuk mengetahui keterbacaan bahan ajar dan kemudahan dalam mendapatkan informasi materi untuk melaksanakan pembelajaran proyek. Hasil uji coba terbatas melalui angket respon mahasiswa dapat dilihat pada Tabel 2.

Tabel 2. Hasil Respon Mahasiswa terhadap

\begin{tabular}{cccl}
\multicolumn{4}{c}{ Penggunaan Bahan Ajar } \\
$\begin{array}{c}\text { Butir } \\
\text { Penilaian }\end{array}$ & Prosentase & $\begin{array}{c}\text { Rata- } \\
\text { Rata }\end{array}$ & Keterangan \\
\hline A. Aspek & $77,3 \%$ & 78,5 & Bahan Ajar \\
keterbacaan & & $\%$ & layak/baik \\
B. Aspek & & & dipergunakan \\
kemudahan & $79,7 \%$ & & dalam \\
mengaskses & & pembelajaran \\
materi & & & Fisika \\
& & Eksperimen \\
& & dan sedikit \\
& & ada \\
& & perbaikan.
\end{tabular}

Respon mahasiswa tentang bahan ajar baik dan membantu dalam mengerjakan tugas perkuliahan Fisika Eksperimen. Hal yang perlu ditambahkan menurut mahasiswa perlunya diberikan contoh yang lebih banyak untuk setiap tahapan scientific method.

Hasil uji coba terbatas terhadap 42 orang mahasiswa untuk mengetahui penguasaan scientific method diperoleh dari hasil observasi dengan menggunakan istrumen penilaian penguasaan scientific method dari semua tahapan proyek. Indikator penguasaan scientific method yang diukur meliputi membuat: membuat pertanyaan ilmiah/merumuskan masalah (ISM1); menentukan judul alat (ISM2); membuat perencanaan/desain alat (ISM3); membuat rancangan eksperimen untuk uji coba alat (ISM4); melakukan uji coba alat (ISM5); membuat laporan tertulis hasil uji coba alat (ISM6);
Tingkat Penguasaan scientific method mahasiswa setelah mengikuti pembelajaran Fisika Eksperimen dapat dilihat pada Gambar 2.

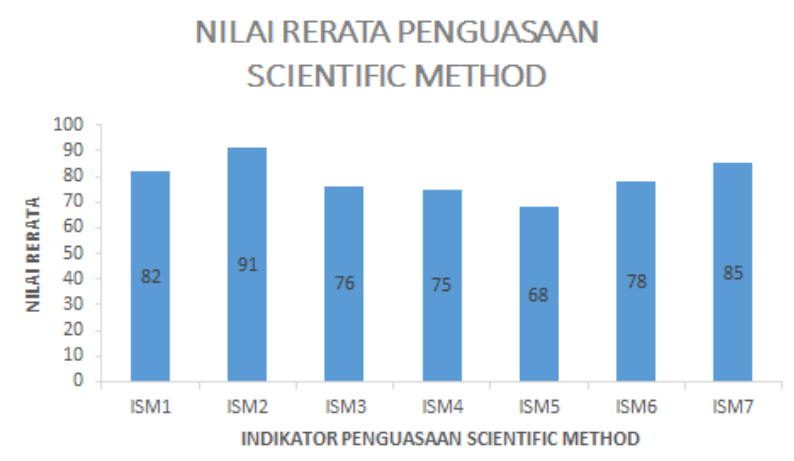

Gambar 2. Rerata Nilai Penguasaan Scientific Method mahasiswa

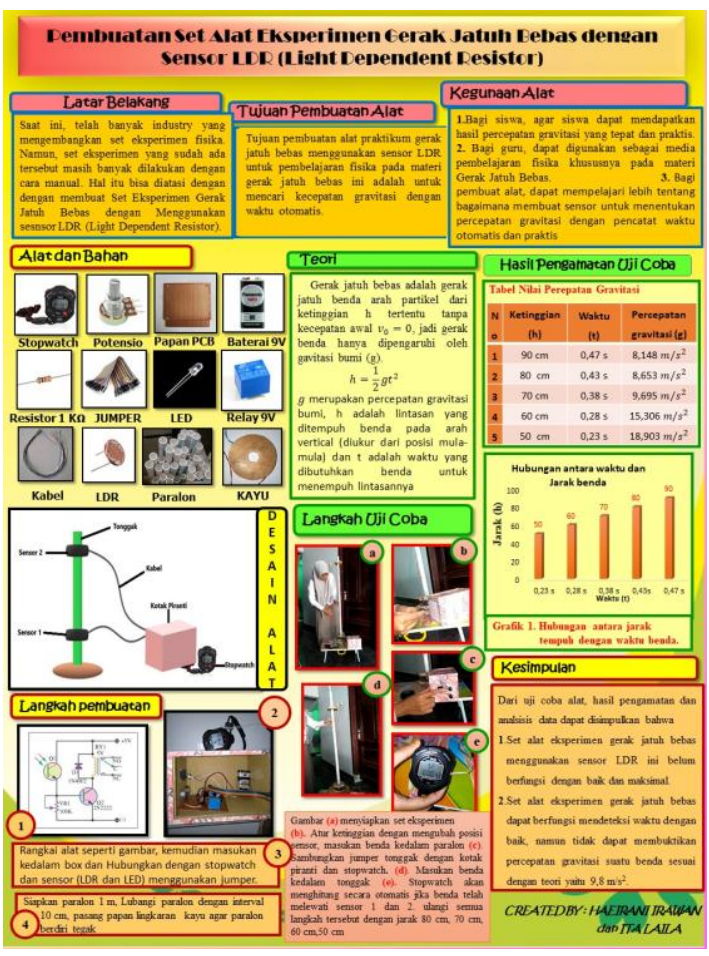

Gambar 3: Poster sebagai hasil publikasi proyek

Dari Gambar 2 menunjukkan tingkat penguasaan scientific mahasiswa dalam kategori baik. Dilihat dari indikator penguasaan scientific method terendah indikator ISM5 membuat laporan tertulis memiliki skor paling rendah. Hal ini disebabkan banyak yang masih mendapatkan nilai yang rendah untuk komponen analisa data dan penarikan kesimpulan. Contoh Poster sebagai publikasi hasil pembelajaran proyek dapat dilihat pada Gambar 3. 
Sutrio et al. (2021). Jurnal Ilmiah Profesi Pendidikan, 6 (1): 126 - 133

DOI: https://doi.org/10.29303/jipp.v6i1.168

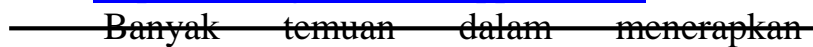
pembelajaran proyek diantaranya mahasiswa juga mampu merancang desain eksperimen berdasarkan alat eksperimen yang dibuat. Rancangan desain eksperimen yang dikembangkan oleh mahasiswa mengikuti tahapan scientific metthod. Pengembangan modul praktikum berbasis saintifik dapat meningkatkan keterampilan proses sains siswa (Astuti et al., 2018). Penguasaan konsep fisika mahasiswa juga bertambah dengan membahas dan mendiskusikan hal-hal baru. Sutrio, et al. (2018) mengembangkan bahan ajar Kajian Fisika Sekolah Menengah berbasis proyek untuk meningkatkan penguasaan konsep fisika SMA calon guru. Pada saat melaksanakan tahap perencanaan dan menguji coba alat mahasiswa harus memiliki kemampuan berpikir kritis dalam memecahkan masalah yang dihadapi. Sutrio, et al. (2018) mengembangkan bahan ajar fisika eksperimen berbasis proyek untuk meningkatkan kemampuan berpikikir kritis calon guru. Wulandari (2016) menyatakan pembelajaran berbasis proyek berpengaruh terhadap kemampuan ketrampilan proses sains mahasiswa seperti melakukan eksploraasi, interpretasi, sintesis dan informasi.

\section{KESIMPULAN}

Berdasarkan hasil penelitian yang telah dilakukan, maka dapat disimpulkan sebagai berikut : (1) Bahan ajar Fisika Eksperimen berbasis proyek yang telah dikembangkan layak/baik digunakan dalam pembelajaran dan memenuhi uji validasi oleh ahli untuk komponen kelayakan isi, penyajian dan kebahasaan dengan kategori baik; (2) Respon mahasiswa setelah menggunakan bahan ajar sangat baik untuk menunjang dan melengkapi bahan ajar pada saat perkuliahan Fisika Eksperimen; (3) Bahan ajar yang diuji cobakan dalam pembelajaran Fisika Eksperimen mampu meningkatkan penguasaan scientific method.

\section{UCAPAN TERIMA KASIH}

Terima kasih kepada Lembaga Penelitian dan Pengabdian pada Masyarakat Universitas Mataram yang telah mendanai penelitian ini dalam bentuk Penelitian Dosen Pemula dibiayai oleh: Sumber Dana DIPA (Daftar Isian Pelaksana Anggaran) BLU (PNBP) Universitas Mataram Tahun Anggaran 2019.

\section{REFERENSI}

Astuti, I. A. D., Putra, I. Y., \& Bhakti, Y. B. (2018). Developing Practicum Module of Particle Dynamics Based on Scientific Methods to Improve Students' Science Process Skills. Scientiae Educatia: Jurnal Pendidikan Sains, 7(2), 183-196.

Erlinawati, C. E., Bektiarso, S., \& Maryani, M. (2019). MODEL PEMBELAJARAN PROJECT BASED LEARNING BERBASIS STEM PADA PEMBELAJARAN FISIKA. FKIP e-PROCEEDING, 4(1), 1-4.

Fitrianingrum, A. M., Sarwi, S., \& Astuti, B. (2016). KEEFEKTIFAN PROJECT BASED LEARNING BERBASIS EKSPERIMEN PADA PENGUASAAN KONSEP DAN KINERJA SISWA SMA. UPEJ Unnes Physics Education Journal, 5(2), 20-27.

Lawson, A. E. (1995). Science teaching and the development of thinking. Belmont, CA: Wadsworth.

Nurohman S, (2007). Pendekatan project base learning sebagai upaya internalisasi scientific method bagi mahasiswa calon guru fisika http:/staff.uny.ac.id (20 Oktober 2015)

Hunkins, F. P., \& Ornstein, A. C. (2016). Curriculum: Foundations, principles, and issues.

Sastrika, I. A. K., Sadia, W., \& Muderawan, I. W. (2013). Pengaruh model pembelajaran berbasis proyek terhadap pemahaman konsep kimia dan keterampilan berpikir kritis. Jurnal Pendidikan dan Pembelajaran IPA Indonesia, 3(2).

Sugiyono, P. (2011). Metodologi penelitian kuantitatif kualitatif dan R\&D. Alpabeta, Bandung.

Sugiyono (2012). Metode Penelitian Kuantitatif, Kualitatif dan $R \& D$. Bandung: Alfabeta.

Sutrio, S., Gunawan, G., Harjono, A., \& Sahidu, H. (2018). Pengembangan Bahan Ajar Fisika Eksperimen Berbasis Proyek Untuk Meningkatkan Keterampilan Berpikir Kritis Calon Guru Fisika. Jurnal Pendidikan Fisika dan Teknologi, 4(1), 131-140. 
Sutrio et al. (2021). Jurnal Ilmiah Profesi Pendidikan, 6 (1): 126 - 133

DOI: https://doi.org/10.29303/jipp.v6i1.168

Strio, (2018). P Fisika Sekolah Menengah Berbasis Proyek untuk meningkatkan penguasaan konsep fisika SMA calon guru. Laporan Penelitian. LPPM Universitas Mataram

Tyler, R. W. (2013). Basic principles of curriculum and instruction. University of Chicago press.

Wulandari, F. E. (2016). Pengaruh Model Pembelajaran Berbasis Proyek untuk Melatihkan Keterampilan Proses

Mahasiswa. PEDAGOGIA: Jurnal

Pendidikan, 5(2), 247-254. 